Published in: Journal of Environmental Radioactivity Vol 157, June 2016, Pages 38-40 https://doi.org/10.1016/j.jenvrad.2016.01.023

\title{
Thirty years after the Chernobyl accident - 30 key papers published in Journal of Environmental Radioactivity
}

\author{
N.A. Beresford ${ }^{1+}$, S. Fesenko², A. Konoplev ${ }^{3}$, J.T. Smith ${ }^{4}$, L. Skuterud ${ }^{5}$, G. Voigt $^{6}$ \\ ${ }^{1,+}$ Centre for Ecology \& Hydrology, Lancaster Environment Centre, Bailrigg, Lancaster LA1 \\ 4AP, UK; ${ }^{2}$ International Atomic Energy Agency, 1400 Vienna, Austria; ${ }^{3}$ Institute of \\ Environmental Radioactivity, Fukushima University, Kanayagawa 1, Fukushima, 960-1296 \\ Japan; ${ }^{4}$ School of Earth and Environmental Sciences, University of Portsmouth, Burnaby \\ Building, Portsmouth, PO1 3QL; ${ }^{5}$ Norwegian Radiation Protection Authority, 1332 Østerås, \\ Norway; ${ }^{6}$ r.e.m., Franz-Siegel-Gasse 26, 2380 Perchtoldsdorf, Austria. \\ ${ }^{+}$Corresponding author \\ Email: nab@ceh.ac.uk; Tel: +44 [0]1524 595856; Fax: +44 [0]1524 61536
}

\section{EDITORIAL}

At 01:23 on $26^{\text {th }}$ April 1986 an experiment was started at reactor number 4 of the Chernobyl nuclear power plant (NPP) in northern Ukraine (then part of the USSR). The purpose of the experiment was to investigate reactor safety in the event of failure of the mains electricity supply to the plant. Less than a minute after the start of the experiment there was a steam explosion which blew the lid off the reactor and resulted in the largest accidental release of radioactivity into the environment in the history of nuclear power production. The exposed reactor core continued to burn for approximately 10 days with continued releases of radioactivity to the atmosphere over this period.

As well as huge contamination in the local area, a radioactive plume was transported over large areas of Europe with the highest depositions of radioactivity at distances from the NPP being due to wet deposition in rainfall.

Between the $27^{\text {th }}$ April (when the $c .44,000$ inhabitants of Pripyat, approximately $3 \mathrm{~km}$ from the NPP, were evacuated) and $6^{\text {th }}$ May the entire population of what has become known as the ' $30 \mathrm{~km}$ zone' around the NPP were evacuated. In total, approximately 116,000 people were initially evacuated from an area of about $3500 \mathrm{~km}^{2}$. Subsequently, the number of evacuees rose to around 350,000 with affected areas located in Ukraine, Belarus and Russia. Many of these areas evacuated remain abandoned today.

A population of about 6 million people in Ukraine, Belarus and Russia were living in areas which were officially designated as contaminated $\left(>37 \mathrm{kBq}^{137} \mathrm{Cs} \mathrm{m}^{-2}\right)$; 640 settlements with approximately 270000 people had in excess of $555 \mathrm{kBq}^{137} \mathrm{Cs} \mathrm{m}^{-2}$. Consequently, the accident led to wide scale remedial actions being applied in these former Soviet Union (fSU) countries both in food production systems and also to decontaminate some settlements. Outside the fSU, long-term remedial measures were put in place on animal production 
systems in Scandinavia and the United Kingdom. In some areas in Scandinavia the culture and live-style of the reindeer herding Sámi people was threatened.

The Chernobyl accident led to a large resurgence in radioecological studies both to aid remediation and to be able to make future predictions on the post-accident situation but also in recognition that more knowledge was required for future accidents. In this on-line virtual special issue we have selected 30 (in our opinion) key papers published in the Journal of Environmental Radioactivity. Whilst necessarily excluding many important papers, in our opinion, the papers selected cover a number of key radioecological questions with a focus on advances made by research conducted following the Chernobyl accident. The areas we identified as being significantly advanced following Chernobyl were: the importance of seminatural ecosystems in dose formation; the characterisation and environmental behaviour of hot particles; the development and application of countermeasures; the "fixation" and long term bioavailability of radiocaesium and; the effects of radiation on plants and animals.

The selected papers are listed below with a short note as to why we selected each. This virtual special issue is accompanied by a review paper published in this issue (Beresford et al. 2016) discussing advances made in radioecology as a consequence of the Chernobyl accident.

Selected papers (in alphabetical order)

Åhman, B., 1999. Transfer of radiocaesium via reindeer meat to man - Effects of countermeasures applied in Sweden following the Chernobyl accident. J. Environ. Radioact. 46, 113-120. http://dx.doi.org/10.1016/S0265-931X(98)00107-6

The sensitivity/vulnerability of the lichen - reindeer - human food chain to radiocaesium contamination was revealed in the 1960s after the nuclear weapons testing, but levels then did not necessitate remediation. The Chernobyl accident consequences for reindeer herding in Sweden and Norway did require remediation. This paper summarizes the efforts, costs and averted doses in Sweden.

Beresford, N.A., Gashchak, S., Lasarev, N., Arkhipov, A., Chyorny, Y., Astasheva, N., Arkhipov, N., Mayes, R.W., Howard, B.J., Baglay, G., Loginova, L., Burov, N., 2000. The transfer of ${ }^{137} \mathrm{Cs}$ and ${ }^{90} \mathrm{Sr}$ to dairy cattle fed fresh herbage collected $3.5 \mathrm{~km}$ from the Chernobyl nuclear power plant. J. Environ. Radioact. 47, 157-170.

http://dx.doi.org/10.1016/S0265-931X(99)00037-5

Field study conducted in the Chernobyl exclusion zone which used: (i) faecal marker approach to estimate herbage, and hence dietary ${ }^{137} \mathrm{Cs}$ and ${ }^{90} \mathrm{Sr}$ intakes; (ii) dual isotope techniques to estimate ${ }^{137} \mathrm{Cs}$ and ${ }^{90} \mathrm{Sr}$ absorption from the gastrointestinal tract.

Beresford, N.A., Voigt, G., Wright, S.M., Howard, B.J., Barnett, C.L., Prister, B., Balonov, M., Ratnikov, A., Travnikova, I., Gillett, A.G., Mehli, H., Skuterud, L., Lepicard, S., Semiochkina, N., Perepeliantnikova, L., Goncharova, N., Arkhipov, A.N., 2001. Self-help countermeasure strategies for populations living within contaminated areas of Belarus, Russia and Ukraine. J. Environ. Radioact. 56, 215-239. http://dx.doi.org/10.1016/S0265$\underline{931 X(01) 00055-8}$

Good overview of key dietary exposure pathways for rural populations in Belarus, Russia and Ukraine together with discussion of how exposure could be minimised. Discusses work on dietary advice in Norway following the Chernobyl accident. 
Bulgakov, A., Konoplev, A., Smith, J., Laptev, G., Voitsekhovich, O., 2009. Fuel particles in the Chernobyl cooling pond: current state and prediction for remediation options. J. Environ. Radioact. 100, 329-332. http://dx.doi.org/10.1016/i.jenvrad.2008.12.012

Demonstrated for the first time the slow dissolution of Chernobyl hot particles in freshwater systems and made predictions of their long term fate.

Calmon, P., Thiry, Y., Zibold, G., Rantavaara, A., Fesenko, S., 2009. Transfer parameter values in temperate forest ecosystems: A review. J. Environ. Radioact. 100, 757-776. http://dx.doi.org/10.1016/j.jenvrad.2008.11.005

A review and reference paper on the improved knowledge of transfer of radionuclides in forest ecosystems during the first two decades after Chernobyl. Includes overview of the transfer to different parts of trees and descriptions of transfer to different nutritional types of mushroom species.

Cooper, E.L., Zeiller, E., Ghods-Esphahani, A., Makarewicz, M., Schelenz, R., Frindik, O., Heilgeist, M., Kalus, W., 1992. Radioactivity in food and total diet samples collected in selected settlements in the USSR. J. Environ. Radioact. 17, 147-157.

http://dx.doi.org/10.1016/0265-931X(92)90023-M

Total diet studies from selected communities in the then USSR considering important dietary contributors to ingestion dose; considers ${ }^{90} \mathrm{Sr}$ and actinides as well as radiocaesium. An early acknowledgement of the significance of fungi to radiocaesium intake.

Desmet, G., Myttenaere, C., 1988. Considerations on the role of natural ecosystems in the eventual contamination of man and his environment. J. Environ. Radioact. 6, 197-202. http://dx.doi.org/10.1016/0265-931X(88)90075-6

Early post-Chernobyl paper recognising the importance of the contribution of natural and semi-natural ecosystems to human doses.

Fesenko, S., Jacob, P., Ulanovsky, A., Chupov, A., Bogdevich, I., Sanzharova, N., Kashparov, V., Panov, A., Zhuchenka, Y., 2013. Justification of remediation strategies in the long term after the Chernobyl accident. J. Environ. Radioact. 119, 39-47.

http://dx.doi.org/10.1016/j.jenvrad.2010.08.012

Updated information on the environmental behaviour of radionuclides. Long-term countermeasures suggested for rehabilitation of the areas most affected by the Chernobyl accident.

Fesenko, S.V., Spiridonov, S.I., Sanzharova, N.I., Alexakhin, R.M., 1997. Dynamics of ${ }^{137}$ Cs bioavailability in a soil-plant system in areas of the Chernobyl nuclear power plant accident zone with a different physico-chemical composition of radioactive fallout. J. Environ.

Radioact. 34, 287-313. http://dx.doi.org/10.1016/0265-931X(96)00044-6

One of the first papers in the international literature on long-term changes in bioavailability of ${ }^{137} \mathrm{Cs}$ in the Chernobyl zone, showing the effect of different factors (i.e. fallout properties, meadow and soil characteristics) on radionuclide behaviour in the soil-plant system.

Garnier-Laplace, J., Geras'kin, S., Della-Vedova, C., Beaugelin-Seiller, K., Hinton, T.G., Real, A., Oudalova, A., 2013. Are radiosensitivity data derived from natural field conditions 
consistent with data from controlled exposures? A case study of Chernobyl wildlife chronically exposed to low dose rates. J. Environ. Radioact. 121, 12-21.

http://dx.doi.org/10.1016/j.jenvrad.2012.01.013

The disparity between effects on wildlife species expected on the basis of many years of laboratory studies and the effects being reported at comparatively low levels in the Chernobyl Exclusion Zone is a key question which needs to be answered. This paper begins to re-evaluate some of the reported field studies.

Geraskin, S.A., Zimina, L.M., Dikarev, V.G., Dikareva, N.S., Zimin, V.L., Vasiliyev, D.V., Oudalova, A.A., Blinova, L.D., Alexakhin, R.M., 2003. Bioindication of the anthropogenic effects on micropopulations of Pinus sylvestris, $L$. in the vicinity of a plant for the storage and processing of radioactive waste and in the Chernobyl NPP zone. J. Environ. Radioact. 66, 171-180. http://dx.doi.org/10.1016/S0265-931X(02)00122-4

A key study into the cytogenetic effects of radiation in the reproductive and vegetative parts of pine trees exposed to radiation.

Hird, A.B., Rimmer, D.L., Livens, F.R., 1995. Total caesium-fixing potentials of acid organic soils. J. Environ. Radioact. 26, 103-118. http://dx.doi.org/10.1016/0265-931X(94)00012-L

Investigation into persistent absence of immobilisation of Chernobyl-derived Cs in upland organic soils in the UK. Organic Cumbrian soils were characterised by high number of Csfixing sites, however, conditions necessary for realisation of this fixing potential did not occur in the field.

Howard, B.J., Beresford, N.A., Voigt, G., 2001. Countermeasures for animal products: A review of effectiveness and potential usefulness after an accident. J. Environ. Radioact. 56, 115-137. http://dx.doi.org/10.1016/S0265-931X(01)00050-9

Review of countermeasures which can be used to manage animal production in contaminated areas which includes consideration of methods used and developed following the Chernobyl accident.

Ivanov, Y.A., Lewyckyj, N., Levchuk, S.E., Prister, B.S., Firsakova, S.K., Arkhipov, N.P., Arkhipov, A.N., Kruglov, S.V., Alexakhin, R.M., Sandalls, J., Askbrant, S., 1997. Migration of ${ }^{137} \mathrm{Cs}$ and ${ }^{90} \mathrm{Sr}$ from Chernobyl fallout in Ukrainian, Belarussian and Russian soils. J. Environ. Radioact. 35, 1-21. http://dx.doi.org/10.1016/S0265-931X(96)00036-7

Comprehensive study (1987-1993) of ${ }^{137} \mathrm{Cs}$ and ${ }^{90} \mathrm{Sr}$ vertical migration in undisturbed soils of the $30 \mathrm{~km}$ zone of the Chernobyl NPP and other severely contaminated areas of Belarus, Russian Federation and Ukraine.

Jacob, P., Fesenko, S., Firsakova, S.K., Likhtarev, I.A., Schotola, C., Alexakhin, R.M., Zhuchenko, Y.M., Kovgan, L., Sanzharova, N.I., Ageyets, V., 2001. Remediation strategies for rural territories contaminated by the Chernobyl accident. J. Environ. Radioact. 56, 51-76. http://dx.doi.org/10.1016/S0265-931X(01)00047-9

One of the first attempts to introduce a quantitative cost estimation into the evaluation of the effectiveness of countermeasures taking into account local socio-economic conditions in the Chernobyl affected areas. 
Kashparov, V.A., Ahamdach, N., Zvarich, S.I., Yoschenko, V.I., Maloshtan, I.M., Dewiere, L. 2004. Kinetics of dissolution of Chernobyl fuel particles in soil in natural conditions. J. Environ. Radioact. 72, 335-353. http://dx.doi.org/10.1016/j.jenvrad.2003.08.002

Rates of decomposition of fuel particles and subsequent radionuclide leaching (transfer from nonexchangeable to exchangeable forms) in soils around the Chernobyl NPP. Identified dependence of fuel particle dissolution rate on soil $\mathrm{pH}$ was discovered.

Kashparov, V.A., Lundin, S.M., Kadygrib, A.M., Protsak, V.P., Levtchuk, S.E., Yoschenko, V.I., Kashpur, V.A., Talerko, N.M., 2000. Forest fires in the territory contaminated as a result of the Chernobyl accident: Radioactive aerosol resuspension and exposure of fire-fighters. J. Environ. Radioact. 51, 281-298. http://dx.doi.org/10.1016/S0265-931X(00)00082-5

The radiological risk from forest fires within the Chernobyl Exclusion Zone is of public concern. This paper describes studies conducted to investigate the processes of resuspension and redistribution of radionuclides by fires.

Konoplev, A., Golosov, V., Laptev, G., Nanba, K., Onda, Y., Takase, T., Wakiyama, Y., Yoshimura, K., 2016. Behaviour of accidentally released radiocesium in soil-water environment: Looking at Fukushima from a Chernobyl perspective. J. Environ. Radioact. 151, 565-578. http://dx.doi.org/10.1016/j.jenvrad.2015.06.019

It is important to draw lessons from Chernobyl which can be applied to understanding the long term fate of radiocaesium following the Fukushima accident. This paper presents key evidence on the similarities and differences in the environmental behaviour of radiocaesium following the two events.

Kryshev, I.I., 1995. Radioactive contamination of aquatic ecosystems following the Chernobyl accident. J. Environ. Radioact. 27, 207-219. http://dx.doi.org/10.1016/0265931X(94)00042-U

Presented for the first time in the international scientific literature, early measurements of the accumulation of radiocaesium in aquatic ecosystems in the fSU after Chernobyl.

Michel, R., Daraoui, A., Gorny, M., Jakob, D., Sachse, R., Romantschuk, L.D., Alfimov, V., Synal, H.-A., 2015. Retrospective dosimetry of Iodine-131 exposures using Iodine-129 and Caesium-137 inventories in soils - A critical evaluation of the consequences of the Chernobyl accident in parts of Northern Ukraine. J. Environ. Radioact. 150, 20-35.

http://dx.doi.org/10.1016/j.jenvrad.2015.07.023

Due to the high uncertainties and incompleteness of radioactivity measurements of ${ }^{131} I$ released during and shortly after the accident the determination of ${ }^{129} I$ has been shown to be a means to reconstruct ${ }^{131}$ I deposition and estimate consequent doses to the public. Results of ${ }^{129}$ I measurements were applied to reconstruct doses in regions in the North of Ukraine.

Murphy, J.F., Nagorskaya, L.L., Smith, J.T., 2011. Abundance and diversity of aquatic macroinvertebrate communities in lakes exposed to Chernobyl-derived ionising radiation. J. Environ. Radioact. 102, 688-694. http://dx.doi.org/10.1016/j.jenvrad.2011.04.007

This study of aquatic invertebrate communities in eight lakes of varying levels of contamination did not find a relationship between radiation dose rate and abundance and diversity of populations. 
Oleksyk, T.K., Novak, J.M., Purdue, J.R., Gashchak, S.P., Smith, M.H., 2004. High levels of fluctuating asymmetry in populations of Apodemus flavicollis from the most contaminated areas in Chornobyl. J. Environ. Radioact. 73, 1-20.

http://dx.doi.org/10.1016/j.jenvrad.2003.07.001

A study which found an increased fluctuating asymmetry of a mouse species at more contaminated sites. It should be noted that whilst ${ }^{137}$ Cs dose was evaluated, as noted by the authors, the dose to bone from ${ }^{90} \mathrm{Sr}$ was not.

Pröhl, G., Ehlken, S., Fiedler, I., Kirchner, G., Klemt, E., Zibold, G., 2006. Ecological halflives of ${ }^{90} \mathrm{Sr}$ and ${ }^{137} \mathrm{Cs}$ in terrestrial and aquatic ecosystems. J. Environ. Radioact. 91, 41-72. http://dx.doi.org/10.1016/j.jenvrad.2006.08.004

Presents long-term trends of ${ }^{90} \mathrm{Sr}$ and ${ }^{137} \mathrm{Cs}$ in various foodstuffs and environmental media, and includes discussions of important limitations in parameters aggregating many factors (such as ecological half-life).

Roed, J., Andersson, K.G., 1996. Clean-up of urban areas in the CIS countries contaminated by Chernobyl fallout. J. Environ. Radioact. 33, 107-116. http://dx.doi.org/10.1016/0265931X(95)00092-O

'Urban radioecology' was born following the Chernobyl accident. This paper presents research on the application of decontamination techniques in urban environments conducted seven years after the Chernobyl accident.

Sandalls, F.J., Segal, M.G., Victorova, N., 1993. Hot particles from Chernobyl: A review. J. Environ. Radioact. 18, 5-52. http://dx.doi.org/10.1016/0265-931X(93)90063-D

The paper showed that the release of fuel particles was a key feature of the Chernobyl source term and prompted researchers to investigate fuel particles decomposition and behaviour in the environment.

Shaw, G., Robinson, C., Holm, E., Frissel, M.J., Crick, M., 2001. A cost-benefit analysis of long-term management options for forests following contamination with ${ }^{137} \mathrm{Cs}$. J. Environ. Radioact. 56, 185-208. http://dx.doi.org/10.1016/S0265-931X(01)00053-4

A study to identify cost effective measures for the management of forested land after radiological contamination.

Skuterud, L., Gaare, E., Eikelmann, I.M., Hove, K., Steinnes, E., 2005. Chernobyl radioactivity persists in reindeer. J. Environ. Radioact. 83, 231-252.

http://dx.doi.org/10.1016/j.jenvrad.2005.04.008

Traditionally ingestion of contaminated lichen was thought of as the reason for the elevated radiocaesium levels in reindeer. This paper demonstrates the importance of other vegetation species in the long-term transfer of radiocaesium to reindeer, and suggests that climatic factors influence regional differences in this transfer.

Smith, J.T., Kudelsky, A.V., Ryabov, I.N., Daire, S.E., Boyer, L., Blust, R.J., Fernandez, J.A., Hadderingh, R.H., Voitsekhovitch, O.V., 2002. Uptake and elimination of radiocaesium in fish and the "size effect". J. Environ. Radioact. 62, 145-164.

http://dx.doi.org/10.1016/S0265-931X(01)00157-6 
An analyses of post-Chernobyl data for freshwater ecosystems showing the dependence of ${ }^{137} \mathrm{Cs}$ uptake on $\mathrm{K}^{+}$concentrations in lake water and also on fish size.

Smith, J.T., Voitsekhovitch, O.V., Håkanson, L., Hilton, J., 2001. A critical review of measures to reduce radioactive doses from drinking water and consumption of freshwater foodstuffs. J. Environ. Radioact. 56, 11-32. http://dx.doi.org/10.1016/S0265-931X(01)00045$\underline{5}$

Key review of countermeasures for application in freshwater systems, including an evaluation of post-Chernobyl measures.

Zibold, G., Drissner, J., Kaminski, S., Klemt, E., Miller, R., 2001. Time-dependence of the radiocaesium contamination of roe deer: measurement and modelling. J. Environ. Radioact. 55, 5-27. http://dx.doi.org/10.1016/S0265-931X(00)00184-3

Elevated radiocaesium levels in roe deer triggered studies of this species in several countries after Chernobyl. This paper is an important quantitative and mechanistic study of long-term trends, elucidating the role of fungi in the transfer of radiocaesium to roe deer in different environments. 